\title{
Reaction between Magnesia-Chrome Brick/Slag Interface by Electric Furnace Static Slag Corrosion Test
}

\author{
Min-Hsiung Hon ${ }^{1}$, Chia-Chan $\mathrm{Hsu}^{1}$ and Moo-Chin Wang ${ }^{2, *}$ \\ ${ }^{1}$ Department of Materials Science and Engineering, National Cheng Kung University, \\ 1 Ta-Hsueh Road, Tainan, 70101, Taiwan, R.O. China \\ ${ }^{2}$ Faculty of Fragrance and Cosmetics, Kaohsiung Medical University, 100 Shi-Chuan 1st Road, \\ Kaohsiung 807, Taiwan, R.O. China
}

Reaction of magnesia-chrome $\left(\mathrm{MgO}-\mathrm{Cr}_{2} \mathrm{O}_{3}\right)$ brick with molten $\mathrm{MgO}-\mathrm{Al}_{2} \mathrm{O}_{3}-\mathrm{SiO}_{2}-\mathrm{CaO}-\mathrm{Fe}_{\mathrm{t}} \mathrm{O}$ slag using electric furnace static corrosion test method was investigated by X-ray diffraction (XRD), optical polarized microscopy (OPM), scanning electron microscopy (SEM), energy dispersive spectrometry (EDS), scanning transmission electron microscopy (STEM) and electron diffraction (ED). From XRD patterns it is found that the crystalline phases at slag-refractory interface are mostly $\mathrm{MgO}$ and $\mathrm{MgCr}_{2} \mathrm{O}_{4}$ with a minor phase of CaMgSiO 4 . The $\mathrm{MgO}$ content in $\mathrm{MgO}-\mathrm{Cr}_{2} \mathrm{O}_{3}$ bricks decreases with temperature increasing. The activity coefficient of $\mathrm{MgO}\left(\gamma_{\mathrm{MgO}}\right)$ in the molten $\mathrm{MgO}_{-}-\mathrm{Al}_{2} \mathrm{O}_{3}-\mathrm{SiO}_{2}-\mathrm{CaO}-\mathrm{Fe}_{\mathrm{t}} \mathrm{O}$ slag also increases with temperature increasing. The diffusion layer of $(\mathrm{Mg}, \mathrm{Fe})(\mathrm{Cr}, \mathrm{Al})_{2} \mathrm{O}_{4}$ is formed between slag area and $\mathrm{MgCr}_{2} \mathrm{O}_{4}$ matrix. [doi:10.2320/matertrans.MRA2007079]

(Received April 2, 2007; Accepted June 21, 2007; Published November 28, 2007)

Keywords: magnesia-chrome brick, $\mathrm{MgO}-\mathrm{Al}_{2} \mathrm{O}-\mathrm{SiO} \mathrm{O}_{2}-\mathrm{CaO}-\mathrm{Fe}_{\mathrm{t}} \mathrm{O}$ slag, electric furnace static slag corrosion test, activity coefficient, diffusion layer, $\mathrm{MgCr}_{2} \mathrm{O}_{4}$ matrix

\section{Introduction}

The conventional ironworks have evolved into a highly efficient operation with high levels of yield and energy efficiency. However, the relatively high capital cost of process plant involved has led to that an increased scale of operation and new blast furnace are typically constructed to produce $2 \sim 3 \mathrm{Mpa}$ to achieve economics of scale. ${ }^{1)}$ A clear trend emerged recently for new process developments in ironmaking to be carried out from virgin ferrous feedstocks with coal as the fuel but without use of the blast furnace are currently the subject of considerable development. ${ }^{2)}$

The direct iron ore smelting reduction (DIOS) process and an environmentally oriented steelmaking process are now the subjects of research. The DIOS process will eliminate the coke oven and sintering plant. ${ }^{3)}$ Although the DIOS process has many advantages, but there are several limiting factors on productivity, including carbonaceous material in slag, slag volume and hot metal temperature, etc. The reduction rate of DIOS process depend on the overall apparent reduction-rate constant and the $\mathrm{FeO}$ content of the foamy slag. As far as productivity is concerned, it is necessary to satisfy the reduction rate and thermal state concurrently within controlled hot metal temperature conditions. ${ }^{3)}$ Hence, selected suitable refractories use in smelting reduction furnace environment such as a high temperature of $1823 \mathrm{~K}$, oxidization atmosphere, lower slag basicity $(\mathrm{Ca} / \mathrm{Si}=1.1)$, and 5.0 mass $\% \mathrm{FeO}$ in slag attained are very important.

Magnesia-chrome $\left(\mathrm{MgO}-\mathrm{Cr}_{2} \mathrm{O}_{3}\right)$ refractories have been widely used in the steel refining process and they are also considered to be strong possible materials for smelting reduction furnaces. ${ }^{4)}$ Corrosion of a refractory due to the chemical dissolution is one of the main causes of refractory wear. The relationship between $\mathrm{MgO}-\mathrm{Cr}_{2} \mathrm{O}_{3}$ refractories and slag has been studied by various investigators. The phase

*Corresponding author, E-mail: mcwang@kmu.edu.tw diagram of $\mathrm{MgO}-\mathrm{Cr}_{2} \mathrm{O}_{3}-\mathrm{SiO}_{2}$ has been published by Keith. ${ }^{5)}$ Glasser and Osborn ${ }^{6}$ have published the phase diagram of $\mathrm{CaO}-\mathrm{Cr}_{2} \mathrm{O}_{3}-\mathrm{SiO}_{2}$ system. Morita et al. ${ }^{7,8)}$ determined the solubilities of $\mathrm{MgO}$ and $\mathrm{Cr}_{2} \mathrm{O}_{3}$ in $\mathrm{CaO}-\mathrm{SiO}_{2}-\mathrm{Al}_{2} \mathrm{O}_{3}-\mathrm{MgO}-$ $\mathrm{Cr}_{2} \mathrm{O}_{3}$ system slag. On the other hand, Tao et al. ${ }^{9,10)}$ also demonstrated that the reactions of magnesia or magnesiachrome refractories with molten $\mathrm{CaO}-\mathrm{SiO}_{2}-\mathrm{Al}_{2} \mathrm{O}_{3}-\mathrm{Fe}_{\mathrm{t}} \mathrm{O}$ slags. However, an extensive literature search shows that details of the corrosion reaction of a $\mathrm{MgO}-\mathrm{Cr}_{2} \mathrm{O}_{3}$ refractory with $\mathrm{CaO}-\mathrm{SiO}_{2}-\mathrm{MgO}-\mathrm{Al}_{2} \mathrm{O}_{3}-\mathrm{Fe}_{\mathrm{t}} \mathrm{O}$ molten slag have not been clarified.

Many different slag tests have been used in the attempt to simulate the environment as refractory is exposed to in commercial service. In the simplest static test, a cup or pocket is filled with slag and exposed to high temperature to promote slag refractory interaction. More sophisticated slag test such as dynamic slag conditions, introduction of fresh slag and thermal cycling. ${ }^{11)}$ The more sophisticated tests are more difficult to operate reproducibly, but offer more potential for meaningful results because they simulate industrial conditions more realistically. Besides, although the simpler slag tests are suffered by being too remote from the real service environment, they are easier to operate and control. ${ }^{11)}$

In the present study, reaction of magnesia-chrome brick at slag-refractory interface by electric furnace static slag corrosion testing has been studied. The slag examined condition were at $1823 \sim 1923 \mathrm{~K}$, oxidization atmosphere, lower slag basicity $(\mathrm{Ca} / \mathrm{Si}=1.1)$ and slag containing $\mathrm{FeO}$ 5.0 mass $\%$. The purpose of this investigation was to clarify the $\mathrm{MgO}$ solubility, microstructure and morphology at the slag-refractory interface for $\mathrm{MgO}-\mathrm{Cr}_{2} \mathrm{O}_{3}$ brick through the electric static slag corrosion test.

\section{Experimental Procedure}

The starting slag used in oxidization atmosphere at 1823 to 
Table 1 Chemical composition of oxide powders used.

\begin{tabular}{|c|c|c|c|c|c|c|c|c|}
\hline \multirow{2}{*}{ Oxide powders } & \multicolumn{8}{|c|}{ Composition (mass\%) } \\
\hline & $\mathrm{SiO}_{2}$ & $\mathrm{Al}_{2} \mathrm{O}_{3}$ & $\mathrm{CaO}$ & $\mathrm{MgO}$ & $\mathrm{Fe}$ & $\mathrm{Pb}$ & $\mathrm{SO}_{4}$ & Others \\
\hline $\mathrm{SiO}_{2}{ }^{\mathrm{a}}$ & 98.92 & & & 0 & 0.01 & 0.01 & 0.05 & 1.01 \\
\hline $\mathrm{CaCO}_{3}{ }^{\mathrm{c}}$ & & & 55.20 & & 0.01 & 0.001 & 0.05 & 44.739 \\
\hline $\mathrm{MgO}^{\mathrm{d}}$ & & & & $>98.00$ & 0.03 & 0.02 & 0.1 & 1.85 \\
\hline
\end{tabular}

a. Nacalai Tesque, INC., Kyoto, Japan

b. J. T. Back, USA

c. Yakuri Chem. Co., Ltd. Osaka, Japan

d. Yakuri Chem. Co., Ltd. Osaka, Japan

Table 2 Source and composition of $\mathrm{FeO}$ used.

\begin{tabular}{ccccccc}
\hline \multirow{2}{*}{ Source } & \multicolumn{5}{c}{ Composition (mass\%) } \\
\cline { 2 - 7 } & $\mathrm{SiO}_{2}$ & $\mathrm{Al}_{2} \mathrm{O}_{3}$ & $\mathrm{CaO}$ & $\mathrm{MgO}$ & $\mathrm{FeO}$ & $\mathrm{Fe}_{2} \mathrm{O}_{3}$ \\
\hline China Steel Corporation & 0.21 & 0.19 & 0.08 & 0.02 & 69.50 & 30.00 \\
\hline
\end{tabular}

Table 3 Chemical composition of the slag.

\begin{tabular}{|c|c|c|c|c|c|}
\hline \multicolumn{5}{|c|}{ Composition (mass\%) } & $C / S^{\mathrm{a}}$ \\
\hline $\mathrm{MgO}$ & $\mathrm{Al}_{2} \mathrm{O}_{3}$ & $\mathrm{SiO}_{2}$ & $\mathrm{CaO}$ & $\mathrm{Fe}_{t} \mathrm{O}^{\mathrm{b}}$ & 1.1 \\
\hline 12.0 & 15.0 & 32.4 & 35.6 & 5.0 & \\
\hline
\end{tabular}

a. $C / S=\mathrm{CaO} / \mathrm{SiO}_{2}$

b. $\mathrm{Fe}_{t} \mathrm{O}$ contained $\mathrm{FeO} 69.50$ mass $\%$ and $\mathrm{Fe}_{2} \mathrm{O}_{3} 30.00$ mass $\%$

$1923 \mathrm{~K}$ was a synthetic $\mathrm{MgO}-\mathrm{Al}_{2} \mathrm{O}_{3}-\mathrm{SiO}_{2}-\mathrm{CaO}-\mathrm{Fe}_{\mathrm{t}} \mathrm{O}$ system. Commercial reagents of $\mathrm{MgO}, \mathrm{Al}_{2} \mathrm{O}_{3}, \mathrm{SiO}_{2}$ and $\mathrm{CaCO}_{3}$ were used. The chemical compositions of these oxide powders are listed in Table 1. The $\mathrm{MgO}-\mathrm{Al}_{2} \mathrm{O}_{3}-\mathrm{SiO}_{2}-\mathrm{CaO}$ premelt slag was fused in an $\mathrm{Al}_{2} \mathrm{O}_{3}$ crucible at $1773 \mathrm{~K}$ in air for $2 \mathrm{~h}$, then quenched in water, dried and ground in a steel mortar. Subsequently, the ground premelt slag was mixed with $\mathrm{FeO}$ to make the described composition for experiments. The composition of $\mathrm{FeO}$ used and chemical composition of the experiment slag are listed in Tables 2 and 3, respectively.

The analyzed specimens for the immersion test $(60 \times$ $60 \times 60 \mathrm{~mm}$ ) were fabricated out of highly-fired directbonded commercial $\mathrm{MgO}-\mathrm{Cr}_{2} \mathrm{O}_{3}$ bricks. The chemical composition and properties of the $\mathrm{MgO}-\mathrm{Cr}_{2} \mathrm{O}_{3}$ bricks are listed in Table 4. The outer crucible for the electric furnace static slag corrosion test $13.2 \mathrm{~cm}$ inside diameter, $15.0 \mathrm{~cm}$ outside diameter, $12.0 \mathrm{~cm}$ depth) was fabricated out castable refractory. A inner fused-alumina crucible $\left(\mathrm{Al}_{2} \mathrm{O}_{3}\right.$ 99.5\%), $11.2 \mathrm{~cm}$ inside diameter, $13.0 \mathrm{~cm}$ outside diameter and $10.0 \mathrm{~cm}$ depth, contained the slag $(300 \mathrm{~g})$ and alumina crucible was set in the castable crucible.

The schematic diagram of the experimental electric furnace and crucibles used for the static slag corrosion test are shown in Fig. 1. Water-cooled caps sealed the upper and lower ends of the steel chamber. Furnace temperature was controlled by a $20 \% \mathrm{Rh} / \mathrm{Pt}-40 \% \mathrm{Rh} / \mathrm{Pt}$ thermocouple connected to the PID program controller.

The castable crucible containing $\mathrm{Al}_{2} \mathrm{O}_{3}$ crucible, slag and sample was set in the furnace and heated up in air atmosphere. After reaching at the testing temperature, 1823 $1923 \mathrm{~K}$, the crucible was held at this temperature for 2 to $8 \mathrm{~h}$. Through corrosion test for a specified time, the $\mathrm{MgO}-\mathrm{Cr}_{2} \mathrm{O}_{3}$
Table 4 Composition and physical properties of the $\mathrm{MgO}-\mathrm{Cr}_{2} \mathrm{O}_{3}$ brick* for slag corrosion test.

\begin{tabular}{|c|c|c|c|c|c|c|c|}
\hline \multirow[b]{2}{*}{ Refractory } & \multicolumn{4}{|c|}{ Composition (mass\%) } & \multicolumn{3}{|c|}{ Physical properties } \\
\hline & $\mathrm{Al}_{2} \mathrm{O}_{3}$ & $\mathrm{MgO}$ & $\mathrm{Fe}_{2} \mathrm{O}_{3}$ & $\mathrm{Cr}_{2} \mathrm{O}_{3}$ & $\begin{array}{l}\text { B.D. }^{\mathrm{a}} \\
\left(\mathrm{g} / \mathrm{cm}^{3}\right)\end{array}$ & $\begin{array}{l}\text { A.P. }^{\text {b }} \\
(\%)\end{array}$ & $\begin{array}{l}\text { C.C.S. } \\
(\mathrm{MPa})\end{array}$ \\
\hline $\mathrm{MgO}-\mathrm{Cr}_{2} \mathrm{O}_{3}$ & 5.0 & 53.2 & 7.3 & 34.5 & 3.3 & 15.3 & 33 \\
\hline $\begin{array}{l}\text { * Provided } \\
\text { a: B.D.: Bu } \\
\text { b: O.P.: Ap } \\
\text { c: C.C.S.: }\end{array}$ & $\begin{array}{l}\text { by suppl } \\
\text { k density } \\
\text { parent po } \\
\text { old crusl }\end{array}$ & $\begin{array}{l}\text { er (Kua } \\
\text { rosity } \\
\text { streng }\end{array}$ & Ho & & & & \\
\hline
\end{tabular}
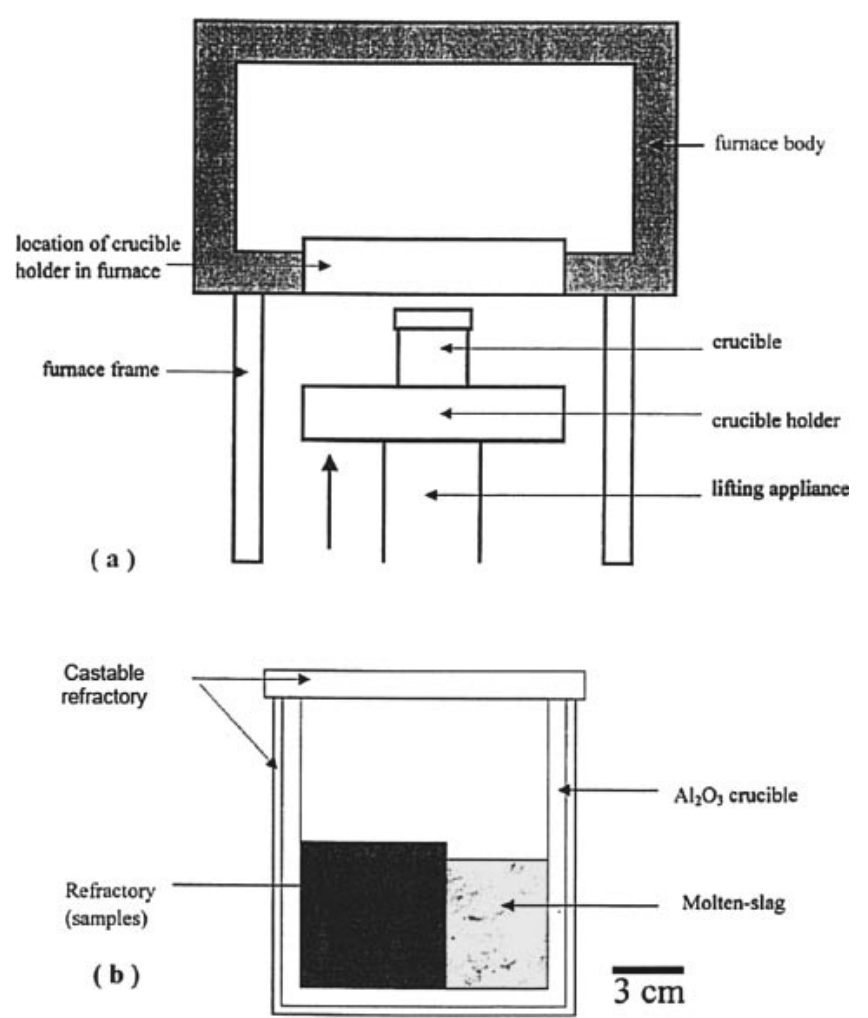

Fig. 1 The schematic diagram of (a) experimental electric furnace and (b) crucible for static slag corrosion test.

brick specimen was removed from the slag by lowering the crucible. After test the specimens were vertically sectioned from the specimen center for corrosion and permeation observation.

The crystalline phase was identified by X-ray diffraction (XRD) which was performed with a Rigaku X-ray diffractometer (Model Rad IIA, Rigaku Co., Tokyo, Japan) with 


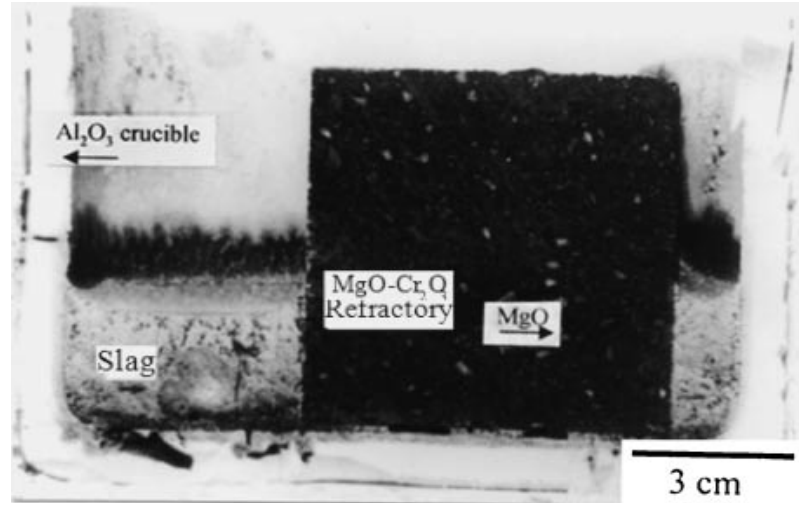

Fig. 2 The cross section morphology of $\mathrm{MgO}-\mathrm{Cr}_{2} \mathrm{O}_{3}$ brick through electric furnace static corrosion test at $1823 \mathrm{~K}$ for $2 \mathrm{~h}$.

$\mathrm{CuK} \alpha$ radiation and a $\mathrm{Ni}$ filter, at a scanning rate $(2 \theta)$ of $0.25^{\circ} / \mathrm{min}$.

The foils for optical polarized microscope (OPM) (Model Nikon E600 POL, Japan) were prepared via the conventional technique: the sample was sliced to a thickness of about $80 \mu \mathrm{m}$ mechanically to optical transparency.

The morphology of the corrosion surface and penetration layer of $\mathrm{MgO}-\mathrm{Cr}_{2} \mathrm{O}_{3}$ brick before and after slag corrosion was examined by scanning electron microscopy (SEM) (Model S-4100, Hitachi Ltd., Tokyo, Japan). The composition was analyzed with energy dispersive spectrometry (EDS) (Model Noran, USA) employing an internal standard method. The mapping and line scannings were attached with the SEM (S-4100).

The foils for transmission electron microscopy (TEM) (Model JEOL 3013, JEOL Ltd., Tokyo, Japan) were prepared via the conventional technique: the sample was taken to the optical thin foils mechanically and ion-beam thinning to electron transparency. Electron diffraction (ED) examinations were made in carefully thinned foils of $\mathrm{MgO}-\mathrm{Cr}_{2} \mathrm{O}_{3}$ bricks after slag corrosion test was operated at an accelerating voltage of $200 \mathrm{kV}$.

\section{Results and Discussion}

The cross section morphology of $\mathrm{MgO}-\mathrm{Cr}_{2} \mathrm{O}_{3}$ brick through electric furnace static corrosion test at $1823 \mathrm{~K}$ for $2 \mathrm{~h}$ is shown in Fig. 2. It indicates that the slag thickness decreases during test, due to the slag penetration into $\mathrm{MgO}$ $\mathrm{Cr}_{2} \mathrm{O}_{3}$ brick and $\mathrm{Al}_{2} \mathrm{O}_{3}$ crucible. The obvious corrosion at interface of slag and brick is not found.

X-ray diffraction (XRD) patterns of $\mathrm{MgO}-\mathrm{Cr}_{2} \mathrm{O}_{3}$ brick before test and heated at $1923 \mathrm{~K}$ through electric furnace static corrosion test for various times are shown in Fig. 3. In Fig. 3(a), it indicates that the crystallization peaks of $\mathrm{MgO}-$ $\mathrm{Cr}_{2} \mathrm{O}_{3}$ brick surface before test as determined by XRD analysis are periclase $\mathrm{MgO}$ and $\mathrm{MgCr}_{2} \mathrm{O}_{4}$ spinel. XRD patterns of the paermeated layer of $\mathrm{MgO}-\mathrm{Cr}_{2} \mathrm{O}_{3}$ brick after corrosion test at $1923 \mathrm{~K}$ for various timews are illustrated in Fig. 3(b)-(d). It indicates that the reflections of $\mathrm{MgO}$ and $\mathrm{MgCr}_{2} \mathrm{O}_{4}$ successively appear, and a minor crystalline phase, $\mathrm{CaMgSiO}_{4}$, also shows up. The crystalline phases are found to be mostly $\mathrm{MgO}$ and $\mathrm{MgCr}_{2} \mathrm{O}_{4}$ with a minor phase of $\mathrm{CaMgSiO}_{4}$ for $\mathrm{MgO}-\mathrm{Cr}_{2} \mathrm{O}_{3}$ at $1823 \mathrm{~K}$ and $1923 \mathrm{~K}$, respec-

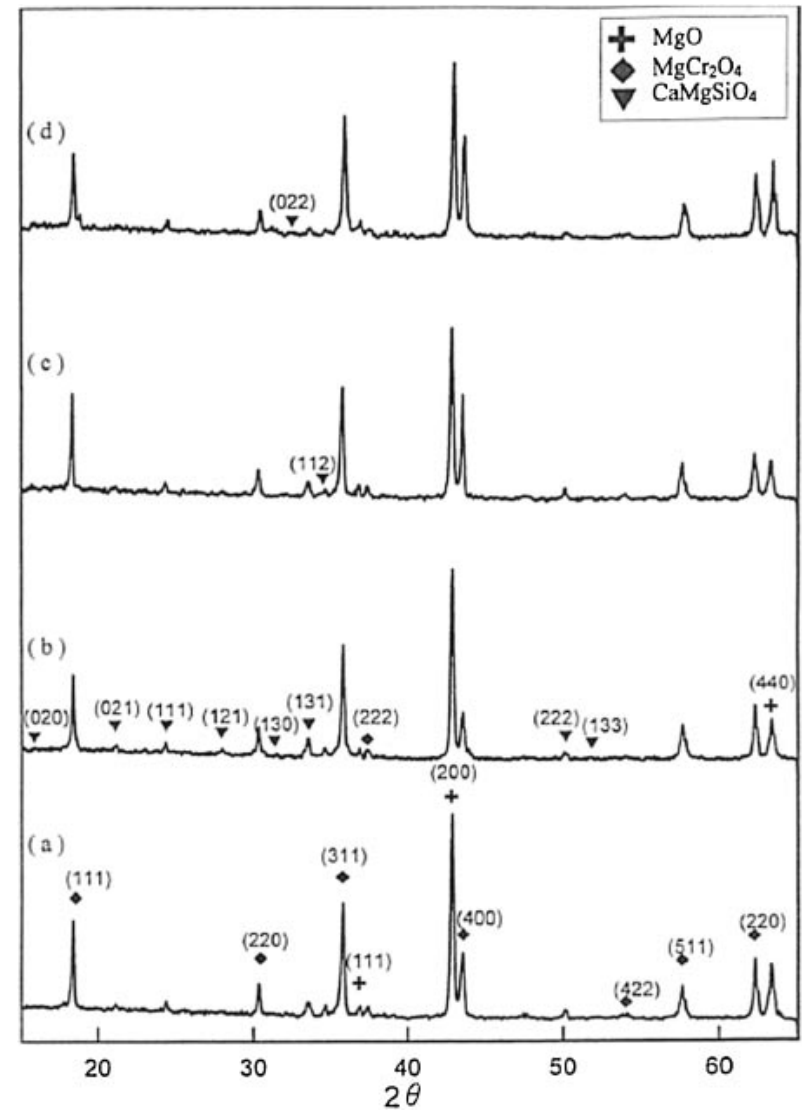

Fig. $3 \mathrm{XRD}$ patterns of the $\mathrm{MgO}-\mathrm{Cr}_{2} \mathrm{O}_{3}$ brick and at $1923 \mathrm{~K}$ through electric furnace static corrosion test for various times: (a) before test, (b) $2 \mathrm{~h}$, (c) $6 \mathrm{~h}$, and (d) $8 \mathrm{~h}$.

tively, after slag corrosion test for various duration time.

The relationship for corrosion test temperature and duration time with the $\mathrm{MgO}$ content in the surface region of $\mathrm{MgO}-\mathrm{Cr}_{2} \mathrm{O}_{3}$ brick is shown in Fig. 4. It indicates that for the same duration, the $\mathrm{MgO}$ content in the surface region of $\mathrm{MgO}-\mathrm{Cr}_{2} \mathrm{O}_{3}$ bricks decreases with increasing corrosion test temperature. This result is caused by the slag attack $\mathrm{MgO}-$ $\mathrm{Cr}_{2} \mathrm{O}_{3}$ brick and corrosion reaction of brick increasing with test temperature increasing. On the other hand, a higher temperature increases the dissolution rate of $\mathrm{MgO}$, because of the higher diffusivity. For the same test temperature, the $\mathrm{MgO}$ content of the surface region of $\mathrm{MgO}-\mathrm{Cr}_{2} \mathrm{O}_{3}$ brick decreases with duration time increasing. When duration time increases from 4 to $8 \mathrm{~h}$, a linear relation for the duration time and the $\mathrm{MgO}$ content is obtained.

The relationship of duration time and test temperature with the $\mathrm{MgO}$ content in slag for $\mathrm{MgO}-\mathrm{Cr}_{2} \mathrm{O}_{3}$ brick through electric furnace static corrosion test is shown in Fig. 5. The increment of $\mathrm{MgO}$ content in slag for $\mathrm{MgO}-\mathrm{Cr}_{2} \mathrm{O}_{3}$ brick test at $1823 \mathrm{~K}$ for $8 \mathrm{~h}$ only increases about $6.0 \%$. But during test at $1923 \mathrm{~K}$ for $8 \mathrm{~h}$, the increment of $\mathrm{MgO}$ content suddenly increases to about $16.0 \%$. Figure 5 indicates that the increment rate of $\mathrm{MgO}$ content in slag for $\mathrm{MgO}-\mathrm{Cr}_{2} \mathrm{O}_{3}$ brick tested at 1923 is higher than that at $1823 \mathrm{~K}$ and $1873 \mathrm{~K}$ for duration time increasing from 4 to $8 \mathrm{~h}$, respectively. This result is due to that as tested at $1923 \mathrm{~K}$, the $\mathrm{MgO}$ content in $\mathrm{MgO}-\mathrm{Cr}_{2} \mathrm{O}_{3}$ brick and slag approaches to equilibrium, when duration time attains to $6 \mathrm{~h}$. 


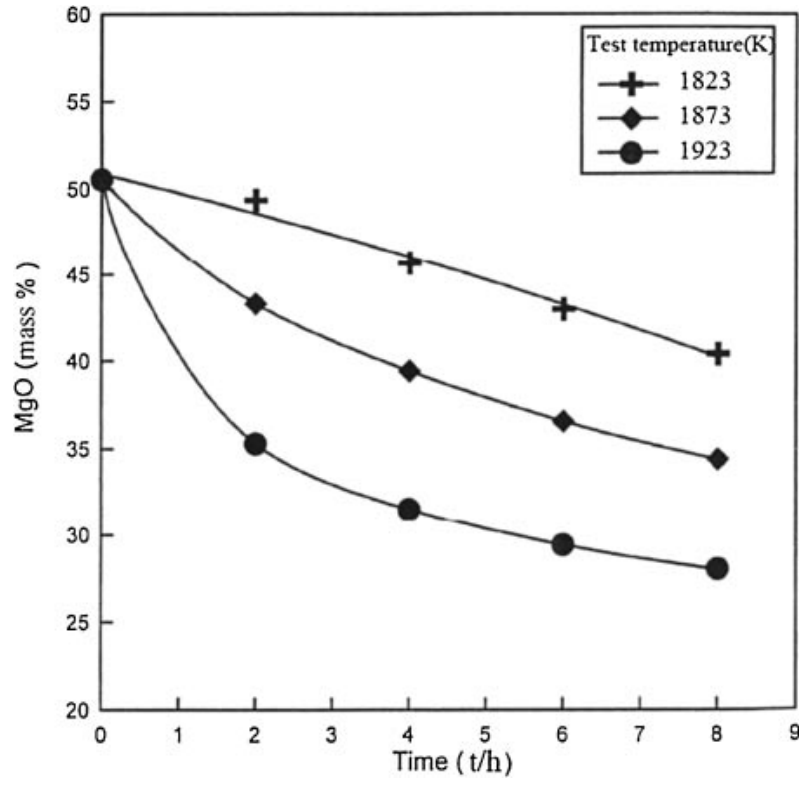

Fig. 4 The relationship of the $\mathrm{MgO}$ content and corrosion test temperature and duration time in the $\mathrm{MgO}-\mathrm{Cr}_{2} \mathrm{O}_{3}$ bricks.

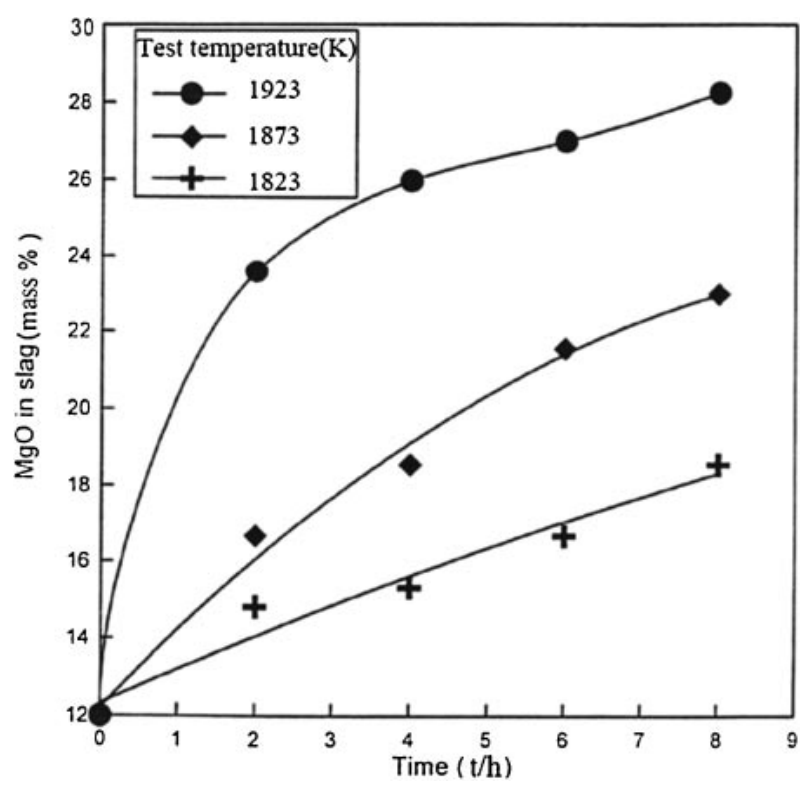

Fig. 5 The relationship of the $\mathrm{MgO}$ content in slag and duration time and test temperature for the $\mathrm{MgO}-\mathrm{Cr}_{2} \mathrm{O}_{3}$ bricks through electric furnace static corrosion test.

The relationship of solubility of $\mathrm{MgO}$ with the slag composition was studied with the regular solution model ${ }^{9,10)}$ in which the molten slag consisting of cations of $\mathrm{Mg}^{2+}, \mathrm{Ca}^{2+}$, $\mathrm{Fe}^{2+}, \mathrm{Al}^{3+}, \mathrm{Si}^{4+}$, etc. and anions of $\mathrm{O}^{2-}$ relating to these cations in molten slag is assumed. The cations are randomly arranged in the space of $\mathrm{O}^{2-} .{ }^{12}$ )

In an $i-j$ binary regular solution system, the activity $\mathrm{a}_{i}$ of component $i$ is obtained from the liquids of the phase diagram and using eq. (1) ${ }^{13)}$

$$
\ln a_{i}=\left(\frac{\Delta H_{m, i}}{R}\right)\left(\frac{1}{T_{m, i}}-\frac{1}{T}\right)
$$

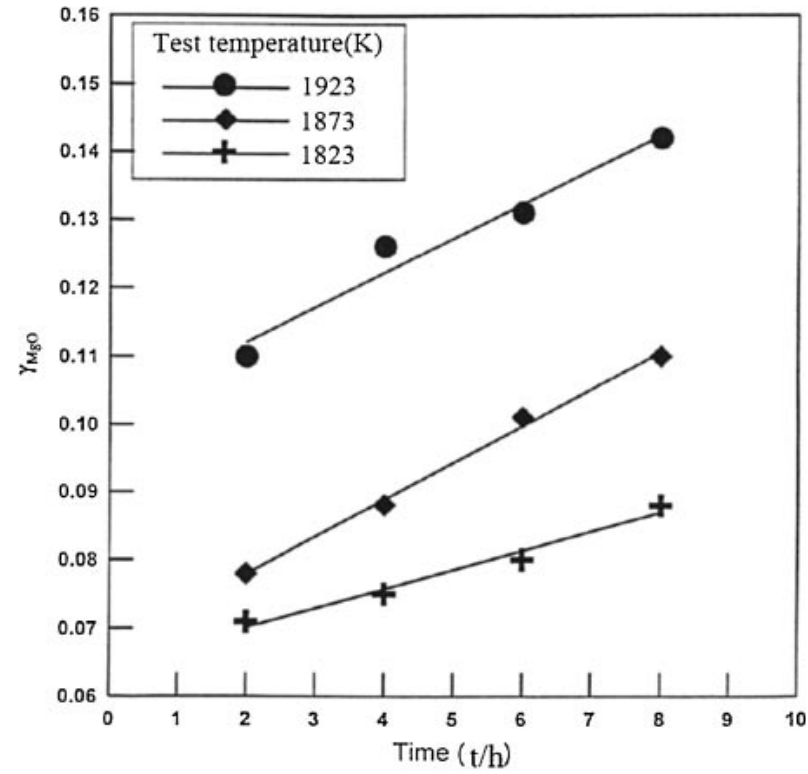

Fig. 6 The relationship of activity coefficient of $\mathrm{MgO}\left(\gamma_{\mathrm{MgO}}\right)$ and test temperature and duration time for the $\mathrm{MgO}-\mathrm{Cr}_{2} \mathrm{O}_{3}$ bricks after electric furnace static slag corrosion test.

where $\Delta H_{m, i}$ is the heat of fusion $(\mathrm{J} / \mathrm{mol}), \mathrm{R}$ is the gas constant $(8.314 \mathrm{~J} / \mathrm{mol}), \mathrm{T}_{m, i}$ is melting point $(\mathrm{K})$ of pure component $\mathrm{i}$, and $\mathrm{T}$ denotes the test temperature $(\mathrm{K})$.

Activity $\mathrm{a}_{i}$ of component $\mathrm{i}$ of a regular solution and activity coefficient $\gamma_{i}$ can be obtained from eqs. (2) and (3): ${ }^{14)}$

$$
\begin{aligned}
& \mathrm{RT} \ln \gamma_{i}=\alpha_{i, j} \cdot x_{j}^{2} \\
& a_{i}=\left(\gamma_{i} x_{i}\right)^{V_{i}}
\end{aligned}
$$

where $\alpha_{i, j}(\mathrm{~J} / \mathrm{mol})$ denotes the interaction energy between (iion)- $\mathrm{O}^{2-}$ (j-ion), $x_{i}$ and $x_{j}$ are mole fractions of components $i$ and $j$, respectively, $V_{i}$ is the number of cations in molecular formula of $i$ component.

Combining and rearranging equations (1), (2) and (3), then the eq. (4) can be obtained:

$$
\alpha_{i, j}=\frac{\Delta H_{m, i}\left(T-T_{m, i}\right)}{v_{i} x_{j}^{2} T_{m, i}}-\frac{R T \ln x_{i}}{x_{j}^{2}}
$$

Applying this regular solution model to $\mathrm{MgO}-\mathrm{Al}_{2} \mathrm{O}_{3}-\mathrm{SiO}_{2}-$ $\mathrm{CaO}-\mathrm{Fe}_{\mathrm{t}} \mathrm{O}$ slag system, the activity coefficient of $\mathrm{MgO}$ can be expressed as equation (5): ${ }^{14)}$

$$
\mathrm{RT} \ln \gamma_{M g O}=\sum_{i \neq j}^{5} \alpha_{i, j} x_{i}-\sum_{i \neq j}^{5} \sum_{j}^{5} \alpha_{i \neq j} x_{i} x_{j}
$$

In the present study, each concentration $\left(x_{i}, x_{j}\right)$ in the liquids and their respective temperature are obtained from each $i-j$ binary system phase diagram. ${ }^{15-21)}$ The data in JANAF Thermochemical Table are used for heat of fusion and melting point of each component. ${ }^{22)}$ Hence, temperature on the liquids and $\alpha_{i, j}$ corresponding to $x_{i}$ and $x_{j}$ are calculated from eq. (4) and putting the value of $\alpha_{i, j}$ into eq. (5).

The calculated results of $\gamma_{\mathrm{MgO}}$ are obtained and shown in Fig. 6. It indicates that the activity coefficient of $\mathrm{MgO}$ in the molten $\mathrm{MgO}-\mathrm{Al}_{2} \mathrm{O}_{3}-\mathrm{SiO}_{2}-\mathrm{CaO}-\mathrm{Fe}_{\mathrm{t}} \mathrm{O}$ slag increases with test temperature increasing for the same time. From Fig. 5, it can be found that the slope of each curre, i.e. the dissolution rate 

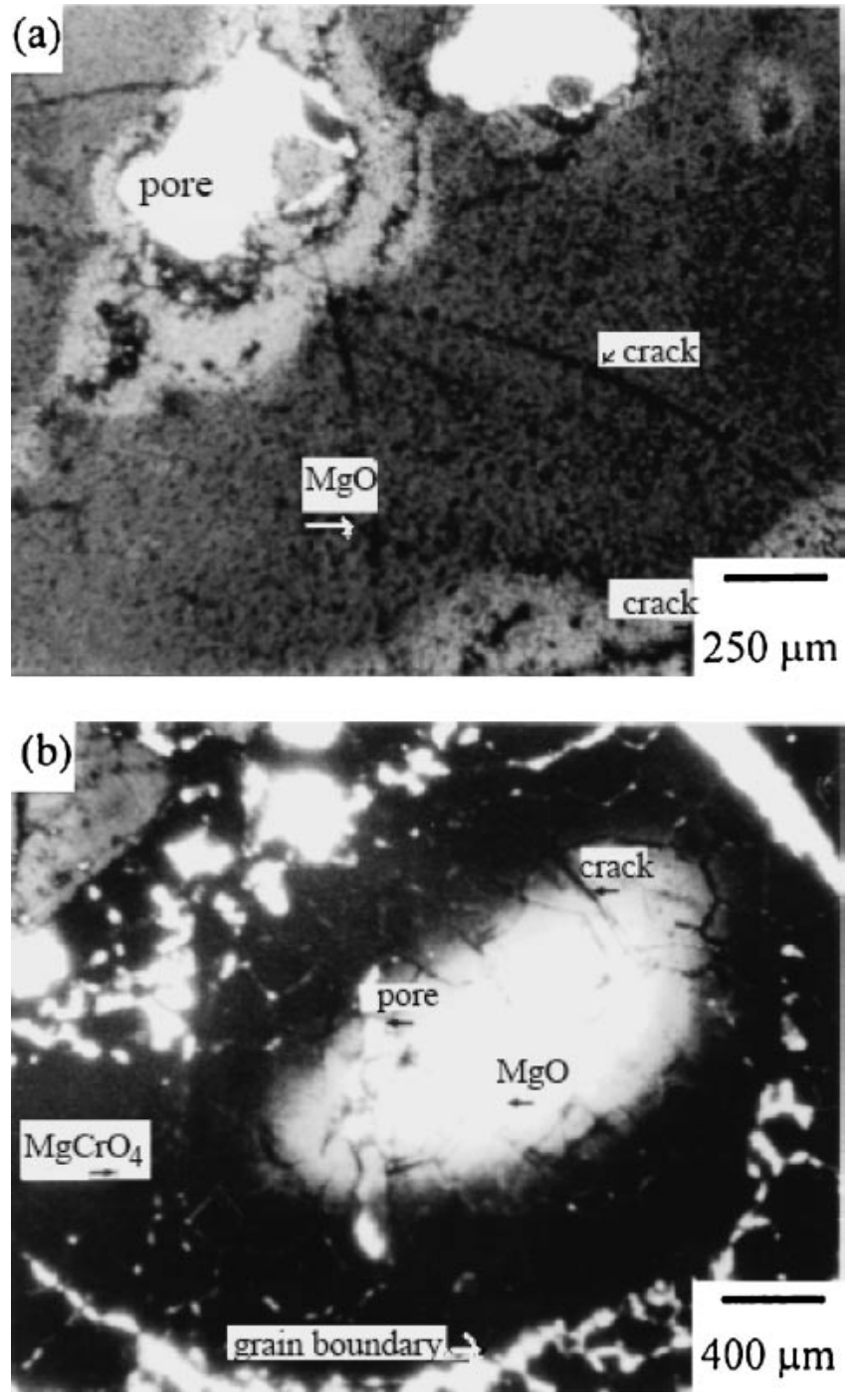

Fig. 7 Optical polarized micrographs of the $\mathrm{MgO}-\mathrm{Cr}_{2} \mathrm{O}_{3}$ bricks through electric furnace static slag corrosion test at various conditions of (a) at $1823 \mathrm{~K}$ for $2 \mathrm{~h}$ and (b) at $1873 \mathrm{~K}$ for $4 \mathrm{~h}$

of $\mathrm{MgO}$ from brick to slag $=\frac{\Delta \mathrm{MgO}_{\text {in slag }}}{\Delta \mathrm{t}}$ increases with the corrosion test temperature at the same time. According to Figs. 5 and 6 , it indicates that the dissolution rate of $\mathrm{MgO}$ increases from brick to slag caused by the activity coefficient of $\mathrm{MgO}$ in slag increases. This result can be corresponding to the result of Tao et al. ${ }^{9,10)}$

Optical polarized micrographs (OPMs) of the $\mathrm{MgO}-\mathrm{Cr}_{2} \mathrm{O}_{3}$ brick through corrosion test at various conditions are shown in Fig. 7. Figure 7(a) shows the open nicols micrograph of $\mathrm{MgO}-\mathrm{Cr}_{2} \mathrm{O}_{3}$ brick through electric furnace static corrosion test at $1823 \mathrm{~K}$ for $2 \mathrm{~h}$. By the extinction and relief of OPM, it can be found the crack, pores, $\mathrm{MgO}$ particles and corrosion reaction area. The corrosion reaction occurs around pores and along crack toward the interior, due to the slag in pores or crack penetrating into $\mathrm{MgO}-\mathrm{Cr}_{2} \mathrm{O}_{3}$ brick. Figure 7(b) shows the open nicols micrograph of $\mathrm{MgO}-\mathrm{Cr}_{2} \mathrm{O}_{3}$ brick at $1873 \mathrm{~K}$ through electric furnace static corrosion test for $4 \mathrm{~h}$. It indicates that the pore fraction and crack increase due to that the corrosion reaction of $\mathrm{MgO}-\mathrm{Cr}_{2} \mathrm{O}_{3}$ brick increases with the test temperature and duration time increasing. The $\mathrm{MgCr}_{2} \mathrm{O}_{4}$ phase is around the reaction area such that $\mathrm{MgO}$ forms the

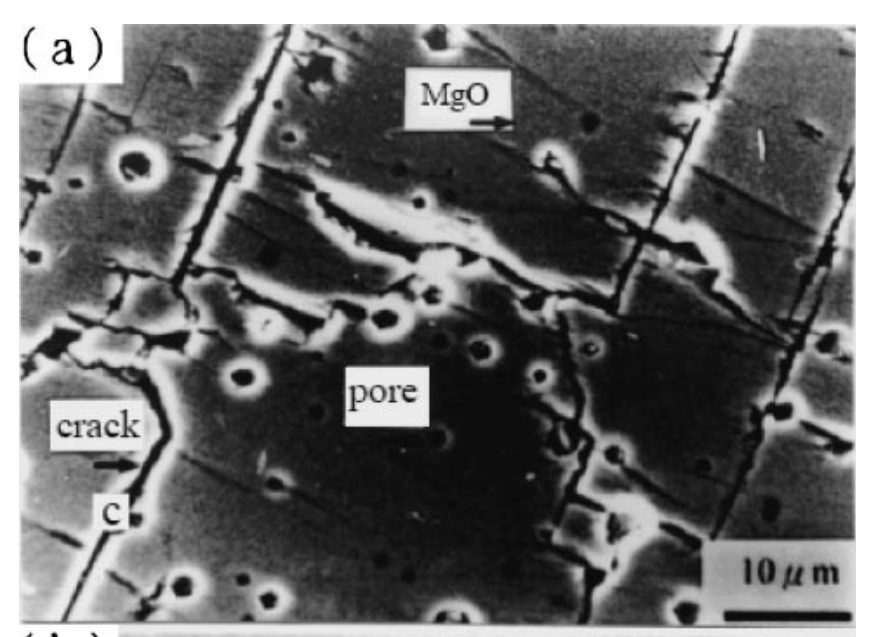

\section{(b)}

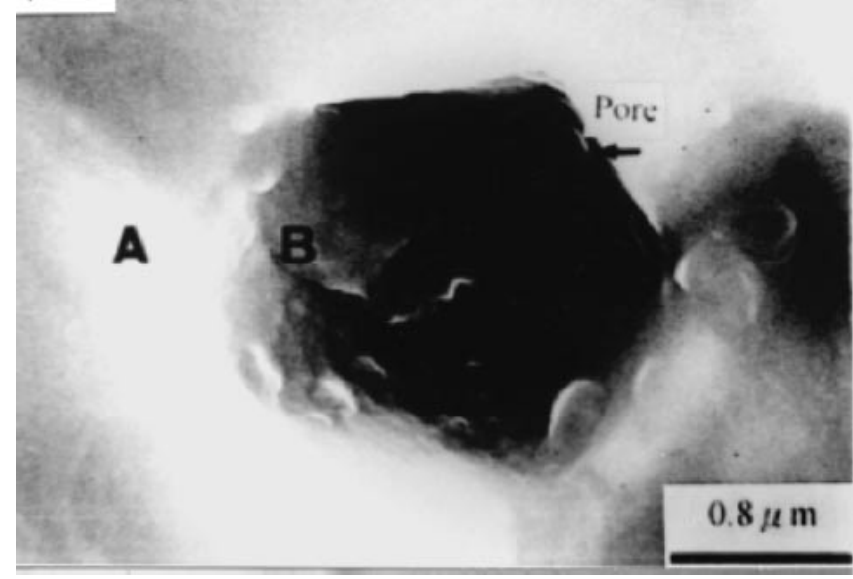

Fig. 8 SEM micrographs of the penetration layer of the $\mathrm{MgO}-\mathrm{Cr}_{2} \mathrm{O}_{3}$ brick at $1823 \mathrm{~K}$ after electric furnace static slag corrosion test for $4 \mathrm{~h}$ : (a) $\mathrm{MgO}$ in penetration layer and (b) enlarged view of the pore (by arrow) in Fig. 8(a).

discontinuous phase. Robin et al. ${ }^{23)}$ have pointed out that the discontinuous phase consists of magnesia grains (periclase) which offers the good corrosion resistance against the aggressive environment and mechanical resistance to thermal loading. From Fig. 7(b) it may be found that the grain boundary is another path of corrosion reaction occurring for $\mathrm{MgO}-\mathrm{Cr}_{2} \mathrm{O}_{3}$ brick with molten slag. According to Figs. 7(a) and (b), it is also found that in the $\mathrm{MgO}-\mathrm{Cr}_{2} \mathrm{O}_{3}$ brick interior, the formation of crack increases with test temperature and duration time increased. This result is caused by that the slag more penetrates into $\mathrm{MgO}$ and accelerates the dissolution of $\mathrm{MgO}$.

The microstructure of scanning electron microscopy (SEM) for the polished permeated layer of $\mathrm{MgO}-\mathrm{Cr}_{2} \mathrm{O}_{3}$ brick at $1823 \mathrm{~K}$ through electric furnace static corrosion test for $4 \mathrm{~h}$ is shown in Fig. 8. Figure 8(a) shows the micrograph of $\mathrm{MgO}$ in the penetration layer. It indicates the crack and pores in the $\mathrm{MgO}$ grains. On the other hand, the corrosion reaction occurs along the grain boundaries of $\mathrm{MgO}$. Figure 8(b) shows the enlarged view of the pore in the Fig. 8(a). Composition of location A (near pore) and location B (in the pore) in Fig. 8(b) are listed in Table 5. It can be found that the $\mathrm{MgO}$ content in the pore is lower than that in the $\mathrm{MgO}$ grain, due to the corrosion reaction of slag with $\mathrm{MgO}$ occurs and forms the sunken hole and creates the eddy 

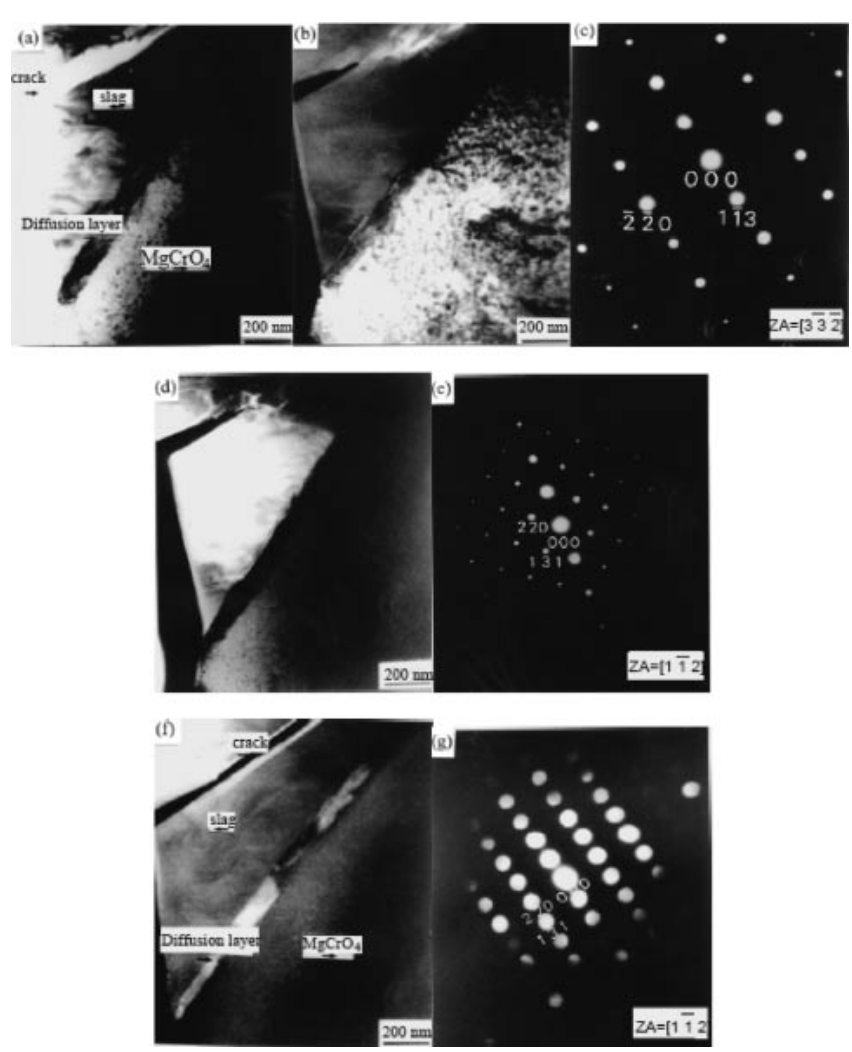

Fig. 9 TEM micrographs and ED patterns of the $\mathrm{MgO}-\mathrm{Cr}_{2} \mathrm{O}_{3}$ brick at $1923 \mathrm{~K}$ after electric furnace static slag test for $4 \mathrm{~h}$ for (a) BF image, (b) DF image of the $\mathrm{MgO}-\mathrm{Cr}_{2} \mathrm{O}_{3}$ brick matrix, (c) ED pattern corresponding to $\mathrm{MgCr}_{2} \mathrm{O}_{4}$ phase, (d) DF image of the slag, (e) ED pattern corresponding to $\mathrm{CaMgSiO}_{2}$ phase, (f) DF image of the diffusion layer between the slag and brick matrix (g) ED pattern corresponding to $(\mathrm{Mg}, \mathrm{Fe})(\mathrm{Al}, \mathrm{Cr})_{2} \mathrm{O}_{4}$ phase.

current such that the stopover time of slag at hole increased, leading to accelerating the dissolution of $\mathrm{MgO}$. Composition of location $\mathrm{C}$ in Fig. 8(a) is also listed in Table 5. For the $\mathrm{MgO}-\mathrm{Cr}_{2} \mathrm{O}_{3}$ brick after slag corrosion, the $\mathrm{MgO}$ dissolves in slag and forms the phase of $\mathrm{CaMgSiO}_{4}$. The melting point of $\mathrm{CaMgSiO}_{4}$ is lower than $1773 \mathrm{~K}$, hence the compound of $\mathrm{CaMgSiO}_{4}$ in slag may penetrate into the exterior of $\mathrm{MgO}$ $\mathrm{Cr}_{2} \mathrm{O}_{3}$ brick. From the results in Table 5 and Fig. 8, it is also found that pores and grain boundaries of $\mathrm{MgO}$ provide the paths for slag penetration into $\mathrm{MgO}-\mathrm{Cr}_{2} \mathrm{O}_{3}$ brick interior and promote the corrosion reaction.

Micrographs of TEM and ED patterns of $\mathrm{MgO}-\mathrm{Cr}_{2} \mathrm{O}_{3}$ brick at $1923 \mathrm{~K}$ after electric furnace static slag corrosion test for $4 \mathrm{~h}$ are shown in Fig. 9. Figure 9(a) shows the morphology of bright field (BF) image, it indicates that a diffusion layer forms between slag and $\mathrm{MgCr}_{2} \mathrm{O}_{4}$ spinel phase in $\mathrm{MgO}$ $\mathrm{Cr}_{2} \mathrm{O}_{3}$ brick matrix. Figure 9(b) shows the dark field (DF) image of $\mathrm{MgCr}_{2} \mathrm{O}_{4}$ spinel, it indicates that the micropores disperse in the $\mathrm{MgCr}_{2} \mathrm{O}_{4}$. The ED pattern (Fig. 9(c)) indexing is corresponding to $\mathrm{MgCr}_{2} \mathrm{O}_{4}$ spinel phase. Figure 9(d) and (e) also show the development of the microstructure of slag and ED pattern in which $\mathrm{CaMgSiO}_{4}$ phase in slag is observed. Figure 9(f) shows the development of the microstructure of diffusion layer. The ED pattern (Fig. 9(e)) also provides the criteria for the presence of ferro magnesiachromite $\left((\mathrm{Mg}, \mathrm{Fe})(\mathrm{Cr}, \mathrm{Al})_{2} \mathrm{O}_{4}\right)$ in this system. From Fig. 9, it also indicates that the slag along crack penetrates into
Table 5 EDS analyses of composition at various locations in Fig. 8.

\begin{tabular}{ccccc}
\hline \multirow{2}{*}{ Location } & \multicolumn{5}{c}{ Composition (mass\%) } \\
\cline { 2 - 5 } & $\mathrm{MgO}$ & $\mathrm{FeO}$ & $\mathrm{SiO}_{2}$ & $\mathrm{CaO}$ \\
\hline $\mathrm{A}$ & 87.62 & 12.38 & - & - \\
$\mathrm{B}$ & 80.54 & 19.46 & - & - \\
$\mathrm{C}$ & 21.3 & 8.5 & 32.7 & 37.5 \\
\hline
\end{tabular}

$\mathrm{MgO}-\mathrm{Cr}_{2} \mathrm{O}_{3}$, interior and with brick occurs corrosion reaction, creates the $(\mathrm{Mg}, \mathrm{Fe})\left(\mathrm{Cr}, \mathrm{Al}_{2} \mathrm{O}_{4}\right.$ phase. The $(\mathrm{Mg}$, $\mathrm{Fe})(\mathrm{Cr}, \mathrm{Al})_{2} \mathrm{O}_{4}$ layer can be effective for inhibiting the penetration of slag and increasing the corrosion resistant of $\mathrm{MgO}-\mathrm{Cr}_{2} \mathrm{O}_{3}$ brick.

\section{Conclusions}

The reaction between $\mathrm{MgO}-\mathrm{Cr}_{2} \mathrm{O}_{3}$ brick and molten $\mathrm{MgO}-$ $\mathrm{Al}_{2} \mathrm{O}_{3}-\mathrm{SiO}_{2}-\mathrm{CaO}-\mathrm{Fe}_{\mathrm{t}} \mathrm{O}$ slag using electric furnace static corrosion test method has been investigated. The results obtained in the present study are summarized as follows:

(1) For the $\mathrm{MgO}-\mathrm{Cr}_{2} \mathrm{O}_{3}$ brick at $1823 \sim 1923 \mathrm{~K}$ through electric static slag corrosion for various duration time by XRD analysis, the crystalline phases are found to be mostly $\mathrm{MgO}$ and $\mathrm{MgO}-\mathrm{Cr}_{2} \mathrm{O}_{4}$ phases with a minor phase of $\mathrm{CaMgSiO}_{4}$.

(2) For same duration time, the $\mathrm{MgO}$ content in $\mathrm{MgO}$ $\mathrm{Cr}_{2} \mathrm{O}_{3}$ bricks decreases with the corrosition test temperature increasing.

(3) The activity coefficient of $\mathrm{MgO}$ in the molten $\mathrm{MgO}$ $\mathrm{SiO}_{2}-\mathrm{CaO}-\mathrm{Fe}_{\mathrm{t}} \mathrm{O}$ slag increases with test temperature increasing for the same time.

(4) Pores and grain boundaries of $\mathrm{MgO}$ provide the paths for slag penetrating into $\mathrm{MgO}-\mathrm{Cr}_{2} \mathrm{O}_{3}$ brick interior and promoting the corrosion reaction.

(5) In the diffusion layer, the phase of $(\mathrm{Mg}, \mathrm{Fe})(\mathrm{Cr}, \mathrm{Al})_{2} \mathrm{O}_{4}$ forms between slag area and $\mathrm{MgCr}_{2} \mathrm{O}_{4}$ matrix.

\section{Acknowledgement}

This work was supported by the Ministry of Economic Affairs of Taiwan, the Republic of China and China Steel Corporation under Contract No. 87R13 and partially supported by the National Science Council of Taiwan, the Republic of China under Contract No. NSC84-2216-E-151005 to which the authors greatly appreciated.

\section{REFERENCES}

1) R. B. Smith: Metals \& Materials. (1992) 491-494.

2) M. J. Corbett: Trans. Instn. Min. Metall. 103 (1994) C21-C25.

3) M. Baba: Trans. Instn. Min. Metall. 103 (1994) C15-C20.

4) T. T. Kahashi: Tetsu to Hagane 80 (1994) 440-445.

5) M. L. Keith: J. Am. Ceram. Soc. 37 (1954) 490-496.

6) E. P. Glasser and E. F. Osborn: J. Am. Ceram. Soc. 41 (1958) 358-367.

7) K. Morita, T. Shibuya and N. Sano: Tetsu to Hagane 74 (1988) 632639.

8) K. Morita, A. Inoue, N. Takayama and N. Sano: Tetsu to Hagane 74 (1988) 999-1005.

9) Z. Tao, K. Mukai, H. Yonezawa and Y. Yoshimura: J. Techno. Asso. Refractories, Jpn. 20 (2000) 10-17.

10) Z. Tao, K. Mukai, H. Yonezawa and Y. Yoshimura: Taikabutsu. 50 
(1998) 573-582.

11) S. V. Gilbert: Ceram. Bull. 55 (1976) 645-648.

12) S. Banya and M. Hino: Tetsu to Hagane 74 (1988) 1701-1711.

13) K. Muraki: Kagakunetsurikigaku no Tsukaikatu, (Kyoritsu Shuppan, 1992) pp. 31-33.

14) X. H. Huang: Principal of Ironmaking and Steelmaking, (Metallurgical Industry Press of China, 1990) pp. 105-107.

15) The American Ceramic Society, Inc. Phase Diagrams for Ceramists, (1964) p. 43

16) The American Ceramic Society, Inc. Phase Diagrams for Ceramists, (1964) p. 54

17) The American Ceramic Society, Inc. Phase Diagrams for Ceramists, (1964) p. 102
18) The American Ceramic Society, Inc. Phase Diagrams for Ceramists, (1964) p. 104.

19) The American Ceramic Society, Inc. Phase Diagrams for Ceramists, (1964) p. 110.

20) The American Ceramic Society, Inc. Phase Diagrams for Ceramists, (1964) p. 112

21) The American Ceramic Society, Inc. Phase Diagrams for Ceramists, (1964) p. 122.

22) D. R. Stull and H. Praphet: JANAF Thermochemical Tables, NSROS (1971).

23) J. M. Robin, Y. Berthaud, N. Schmitt, J. Poirier and D. Themines: Brit. Ceram. Trans. 97 (1998) 1-10. 